\title{
POPULATION FLUCTUATIONS OF CERTAIN MITES ASSOCIATED WITH SOYBEAN AND COTTON PLANTS IN RELATION TO CLIMATIC FACTORS AND LEAF PHYTOCHEMICAL CONTENTS
}

\author{
KALMOSH, FATMA. SH. ${ }^{1}$; E.F. EL-KHAYAT ${ }^{2}$, G. H. RADY', \\ O. M. O. MOHAMED ${ }^{1}$ and TAHANY R. ABDEL-ZAHIR ${ }^{2}$
}

1. Plant Protection Research Institute, ARC, Dokki Giza,Egypt.

2. Faculty of Agriculture, Benha University, Moshtohor, Egypt.

(Manuscript received 22 November 2015)

\begin{abstract}
$\mathrm{P}$

opulation fluctuations of certain mites associated with soybean and cotton plants were investigated during seasons, 2012 and 2013 at Sharkia Governorate, as well as its relation with some prevailing climatic factors. In soybean plants, the population of phytophagous mite, Tetranychus urticae Koch was recorded in high number in $2^{\text {nd }}$ season than the $1^{\text {st }}$ one, whereby represented by 272.83 and 202.69 individuals, respectively. While, the predacious mite, Phytoseiulus macropilis (Banks) recorded in high number in $1^{\text {st }}$ season than the $2^{\text {nd }}$ season were aggregated 37.72 and 25.91 individuals, respectively; on soybean plants. The population of $T$. urticae was higher in $1^{\text {st }}$ year than the $2^{\text {nd }}$ year (394.92 and 367.65 individuals, respectively; while the predacious mites were high in the $2^{\text {nd }}$ year than that obtained in the $1^{\text {st }}$ one on cotton plants. These results revealed that there is negative significant relation between the predacious mite species and the phytophagous mite species on soybean and cotton plants. The population of the spider mite $T$. urticae was significantly related to the leaf contents of protein and phosphorous, while there was no significance between the predator ( $P$. macropilis) with leaf phytochemical contents of soybean during two seasons 2012/13. The population of the spider mite and leaf phytochemical contents of cotton during season 2013 revealed that there is highly significant correlation between the pest mite $T$. urticae with protein, carbohydrate, total sugar and reducing sugar, while there was no significance between the pest and non-reducing sugar. The population revealed that there is no significant correlation between the predator Typhlodromus californicus with protein, carbohydrate, reducing sugar and non-reducing sugar. The correlation coefficient was significant between the predator Agistemus exsertus and carbohydrate, total sugar and reducing sugar, they also recorded a highly significant correlation between the predator and protein; while there was no significance difference between the two predators ( $A$. swiriskii \& E. scutalis) with phytochemical contents.
\end{abstract}

\section{INTRODUCTION}

Cotton, Gossypium barbadense L. and soybean, Glycine max (L.) Merr. occupy an important position among field crops in Egypt, while cotton has traditionally been 
the most important fiber crop in Egypt and the leading agricultural export crop and soybean which used for human consumption and oil extraction. Cotton and soybean are heavily infested by the phytophagous mite, Tetranychus urticae, Koch which considered one of the most important mites infesting many crops in the world and frequently causes a considerable loss in yield and fiber quality (Wilson et al., 1993, ElKhouly et al., 1998 and Taha et al., 2001).

The wide use of pesticides for controlling cotton and soybean pests has hazard side effects on the wild life, human health and inducing considerable problems in the environmental balance between pests and its related biological agents. (John et al., 1986). However, varieties of soybean exhibit variable reactions to the sucking pests infestation depending on plant physical properties or chemical components of plant leaves (Zaher et al., 1980; Hildebrand et al., 1986; McAuslane et al., 1995 and McAuslane, 1996) as biochemical factors to a large extent, affect the behavior and metabolic processes of pest, while morphological factors mostly influence the mechanisms of locomotion, feeding, oviposition, ingestion and digestion of the pest (Kumar, 1984). Also, plan resistance to insects is generally derived from certain biochemical and / or the metabolism of insects which affect the damage caused by these insects (Metcalf and William, 1975).

So, the present work was carried out to study the population fluctuation of mites associated with soybean variety (Giza 311 ) and Cotton at Sharkia Governorate during two seasons, as well as, its relation with some prevailing weather factors and chemical contents of leaves.

\section{MATERIALS AND METHODS}

\section{Population fluctuation studies of mite species associated with Soybean (Giza 311 variety) and cotton crops:}

The present experiment was carried out at Hehia distract, Sharkia Governorate through 2012 and 2013 seasons. Samples (40 leave each) were collected randomly at early morning from cotton and soybean infested field. All collected samples were kept in paper bags. Necessary information including crop locality and date of collection and sowing were recorded.

Samples were directly transferred to the laboratory and examined using stereomicroscope to compare occurrence of the identified species on each crop. This process repeated weekly at the same region, as well as the temperature and relative humidity were recorded. All mite species were identified at Acarology Dept. Plant Protection Research Institute Sharkia Branch. 


\section{Chemical analysis:}

\subsection{Samplying technique:}

Weekly samples of (40 leaves) were collected randomizely from field and transformed in paper bags to laboratory and dried in vain at $35^{\circ} \mathrm{C}$.

\subsection{Determination of carbohydrate fractions:}

One gram of dried leaves was hydrolysed by addition of $50 \mathrm{ml}$ of $0.8 \mathrm{~N}$ sulphuric acid, for 16 hours under a reflux condenser on a boiling water bath, then filtered and the filtrate was transferred into neutralized with $2 \mathrm{~N} \mathrm{NaOH}$, clarified with lead acetate and transferred into measuring flask and completed with distilled water to $100 \mathrm{ml}$ with. Ten $\mathrm{ml}$ of the filtrate were transferred into a $25 \mathrm{ml}$ measuring flask and completed with distilled water. One $\mathrm{ml}$ was taken from a $25 \mathrm{ml}$ measuring flask in a test tube, $4 \mathrm{ml}$ of distilled water and $2 \mathrm{ml}$ of 3,5 dinitrosalicylic acid were added, mixed well, then heated in a boiling water bath for $10 \mathrm{~min}$. After cooling to room temperature the density of the developed colour was measured with Spectrophotometer at $550 \mathrm{~nm}$ using (spectronic 20 colorimeter). Concentration of sugars was obtained according to a standard calibration curve prepared by the same way using glucose, then calculated as mg glucose / $100 \mathrm{mg}$ dry weight.

\subsection{Preparation of crude ethanolic extract:}

Approximately one gram of the dried leaves was used for the extraction of total soluble sugars by boiling in $80 \%$ of aqueous ethanol for 8 hours under a reflex condenser. The extract was filtrated and evaporated to dryness under reduced pressure, then the residue was taken up in a $50 \mathrm{ml}$ measuring flask with $10 \%$ isopropanol. The ethanolic extract was used for the determination of total soluble carbohydrate and total reducing sugars.

\subsection{Determination of total soluble sugars:}

Twenty $\mathrm{ml}$ of soluble sugars extract were taken in to a $100 \mathrm{ml}$ conical flask, then $10 \mathrm{ml}$ of $0.8 \mathrm{~N}$ sulphuric acid was added and the mixture was hydrolyzed under a refluxing condenser on a boiling water bath for 4 hours. The hydrolyzate was then neutralized with $2 \mathrm{~N} \mathrm{NaOH}$ solutions and adjusted to $50 \mathrm{ml}$ with distilled water. Ten $\mathrm{ml}$ of the diluted hydrolyzate was transferred into a $25 \mathrm{ml}$ measuring flask and completed with distilled water. Five $\mathrm{ml}$ of the diluted hydrolyzate were taken in a test tube and $2 \mathrm{ml}$ of 3, 5 dinitrosalicylic acid (reagent 1) was added. The mixture was heated on a water bath for $10 \mathrm{~min}$, then the developed colour was measured by a Spectronic 20 colorimeter at $550 \mathrm{~nm}$, total soluble sugar concentration was calculated from standard calibration curve for glucose as mg glucose / $100 \mathrm{mg}$ dry matter according to A.O.A.C. (2000). 
564 POPULATION FLUCTUATIONS OF CERTAIN MITES ASSOCIATED WITH SOYBEAN AND COTTON PLANTS IN RELATION TO CLIMATIC FACTORS AND LEAF PHYTOCHEMICAL CONTENTS

\subsection{Determination of reducing sugars:}

Eight $\mathrm{ml}$ of the ethanolic extract containing total soluble sugars was transferred into a $25 \mathrm{ml}$ measuring flask, and completed with distilled water, then 5 $\mathrm{ml}$ of the solution were pipptted in a test tube, followed by addition of $2 \mathrm{ml}$ of reagent (1). The test tube was then heated and the developed colour was measured after cooling to room temperature and reducing sugars were obtained from a standard calibration curve for glucose as above and calculated as mg glucose / $100 \mathrm{mg}$ dry matter according to A.O.A.C. (2000).

\subsection{Determination of non-reducing sugars:}

The difference between the percentage of total soluble sugars and reducing sugars was taken as the percentage of non-reducing sugars. (\% non-reducing sugars $=\%$ total soluble sugars $-\%$ total reducing sugars) according to A.O.A.C. (2000).

\subsection{Determination of crud protein:}

The crude nitrogen content of soybean and cotton leaf was determined by micro-Kjeldahl method. Crude protein content was calculated as percentage of the dry weight bases by multiplying crude nitrogen percentage by the conversion factor of 6.25 according to A.O.A.C. (2000).

\subsection{Determination of phosphorus content:}

Phosphorus content was determined by flame photometer according to the method described by Jackson (1970).

\section{RESULTS AND SISCUSSION}

Data in Table (1) showed that sixteen mite species belonging to four families were identified in the total collected samples (cotton \& soybean). From the economical point of view the identified Acari can be classified according to their feeding habits to three major groups; phytophagous mites, predaceous mites and uncertain feeding behavior mites.

\section{Soybean:}

Data in Tables (2\&3) and Figs., (2\&3) revealed that the population of Tetranychus urticae Koch has a single high peak in the first week of August recording was 56.73 individual / soybean leaflet in the first season (2012) while it was 77.5 individuals/ soybean leaflet in the second season (2013).

Data in Tables (2\&3) and Figs., (2\&3) showed that the population of predacious mite Phytoseiulus macropilis was highly increased in the first week of August in both two seasons of study and it was the same (13.25 individuals / leaflet). 
Data obtained in Tables (2\&3) showed that the total population of the phytophagous mite $T$. urticae was high in the second season (272.825 individuals/ leaflet) compared with the first one (202.69 individuals/ leaflet). On the other hand, the predacious mite $P$. macropilis was higher in the first season (37.72 individuals/ leaflet) than that the second one (25.91 individuals/ leaflet).

As shown from obtained data in Figures (2\&3) there is a clear relation between the predacious mite and the phytophagous mites.

Table 1. Survey of mite species associated with two field crops (cotton \& soybean) in Hehia district, Sharkia Governorate.

\begin{tabular}{|c|c|c|}
\hline Mite species & Host Plant & Population \\
\hline \multicolumn{3}{|l|}{ I. Predacious mites: } \\
\hline $\begin{array}{l}\text { I.1.Family: Phytoseiidae Berlese } \\
\text { Amblyseius swirskii Athias-Henriot }\end{array}$ & Soybean \& Cotton & Moderate \\
\hline Amblyseius zaheri Yousef and El-Brollosy & Soybean & Moderate \\
\hline Amblyseius enab El-Badry & Soybean & Rare \\
\hline Amblyseius cucumaris (Oudemans) & Soybean \& Cotton & Low \\
\hline Amblyseius yousefi Zaher and El-Brollosy & Cotton & Low \\
\hline Euseius scutalis ( Athias-Henriot) & Soybean \& Cotton & High \\
\hline Phytoseiulus macropilis (Banks) & Soybean & High \\
\hline Typhlodromus cardiae & Soybean \& Cotton & Low \\
\hline Typhlodromus californicus McGregor & Cotton & Low \\
\hline Typhlodromus pyri Schueten & Cotton & Rare \\
\hline Typhlodromus zaheri Denmark & Soybean \& Cotton & Low \\
\hline $\begin{array}{l}\text { I.2.Family:Stigmaeidae Oudemans } \\
\text { Agistemus exsertus Gonzalez }\end{array}$ & Cotton & High \\
\hline $\begin{array}{l}\text { II. Phytophagous mites } \\
\text { II.1.Family:Tetranychidae Donnadien } \\
\text { Tetranychus urticae Koch }\end{array}$ & Soybean \& Cotton & High \\
\hline Tetranychus cucurbitacearum (Sayed) & Soybean \& Cotton & High \\
\hline $\begin{array}{l}\text { III.Uncertain feeding behavior mites } \\
\text { III.1. Family: Tydeidae Kramer } \\
\text { Tydeus oregonesis Baker }\end{array}$ & Cotton & Low \\
\hline Tydeus californicus (Banks) & Cotton & Moderate \\
\hline
\end{tabular}

High= Cosmopolitan, recorded in most samples.

Moderate $=$ Recorded in $50 \%$ of the samples.

Low $=$ Recorded in $25 \%$ of the samples.

Rare $=$ Recorded in less than $10 \%$ of the samples. 
566 POPULATION FLUCTUATIONS OF CERTAIN MITES ASSOCIATED WITH SOYBEAN AND COTTON PLANTS IN RELATION TO CLIMATIC FACTORS AND LEAF PHYTOCHEMICAL CONTENTS

Table 2. Population fluctuations of mites associated with Soybean plants during season 2012.

\begin{tabular}{|c|c|c|c|c|}
\hline Inspection date & T.urticae & P. macropilis & $\begin{array}{c}\text { Mean } \\
\text { temperature }\end{array}$ & R.H\% \\
\hline July, $1^{\text {st }}$ & 3.125 & 0.53 & 27.29 & 42.29 \\
\hline July, $8^{\text {th }}$ & 26.23 & 1.33 & 27.71 & 44.86 \\
\hline July, 15 $5^{\text {th }}$ & 47.35 & 1.075 & 28 & 47.71 \\
\hline July, 22th & 54.85 & 3.175 & 29.86 & 55 \\
\hline July, 29 & 56.73 & 11.63 & 29.71 & 54.71 \\
\hline August, $5^{\text {th }}$ & 12.73 & 13.25 & 29 & 54.71 \\
\hline August, $12^{\text {th }}$ & 1.15 & 1.8 & 28.86 & 54 \\
\hline August, $19^{\text {th }}$ & 0.075 & 0.25 & 31.43 & 48.86 \\
\hline August, $29^{\text {th }}$ & 0.025 & 0.55 & 30 & 58.71 \\
\hline September, $2^{\text {nd }}$ & 0.05 & 0.45 & 30.29 & 57.57 \\
\hline September, $9^{\text {th }}$ & 0 & 0.15 & 30 & 53.57 \\
\hline September, $16^{\text {th }}$ & 0.175 & 1.8 & 31 & 44.57 \\
\hline September, 23th & 0.2 & 1.73 & 29.71 & 54.57 \\
\hline Total & 202,69 & 37.72 & & \\
\hline
\end{tabular}

Table 3. Population fluctuations of mites associated with soybean plants during season 2013.

\begin{tabular}{|c|c|c|c|c|}
\hline Inspection date & T.urticae & P. macropilis & Mean temperature & R.H\% \\
\hline June, $27^{\text {th }}$ & 0.5 & 0.53 & 25.7 & 69 \\
\hline July, $4^{\text {th }}$ & 6.25 & 1.33 & 25.9 & 68.21 \\
\hline July, $11^{\text {th }}$ & 8.6 & 1.075 & 25.36 & 73.14 \\
\hline July, $18^{\text {th }}$ & 30 & 3.175 & 24.53 & 72.71 \\
\hline July, $25^{\text {th }}$ & 74 & 0.55 & 25.62 & 68.14 \\
\hline August, $1^{\text {st }}$ & 74.5 & 13.25 & 25.84 & 67.79 \\
\hline August, $8^{\text {th }}$ & 77.5 & 1.5 & 26.8 & 69 \\
\hline August, $15^{\text {th }}$ & 1.15 & 2.75 & 23.8 & 74 \\
\hline August, 22 th & 0.075 & 1.75 & 26.4 & 67 \\
\hline August, $29^{\text {th }}$ & 0.025 & 0 & 25.4 & 68 \\
\hline September, $5^{\text {th }}$ & 0.05 & 0 & 26 & 69 \\
\hline September, $12^{\text {th }}$ & 0 & 0 & 22.7 & 73 \\
\hline September, $19^{\text {th }}$ & 0.175 & 0 & 23.6 & 72 \\
\hline Total & 272.82 & 25.91 & & \\
\hline
\end{tabular}



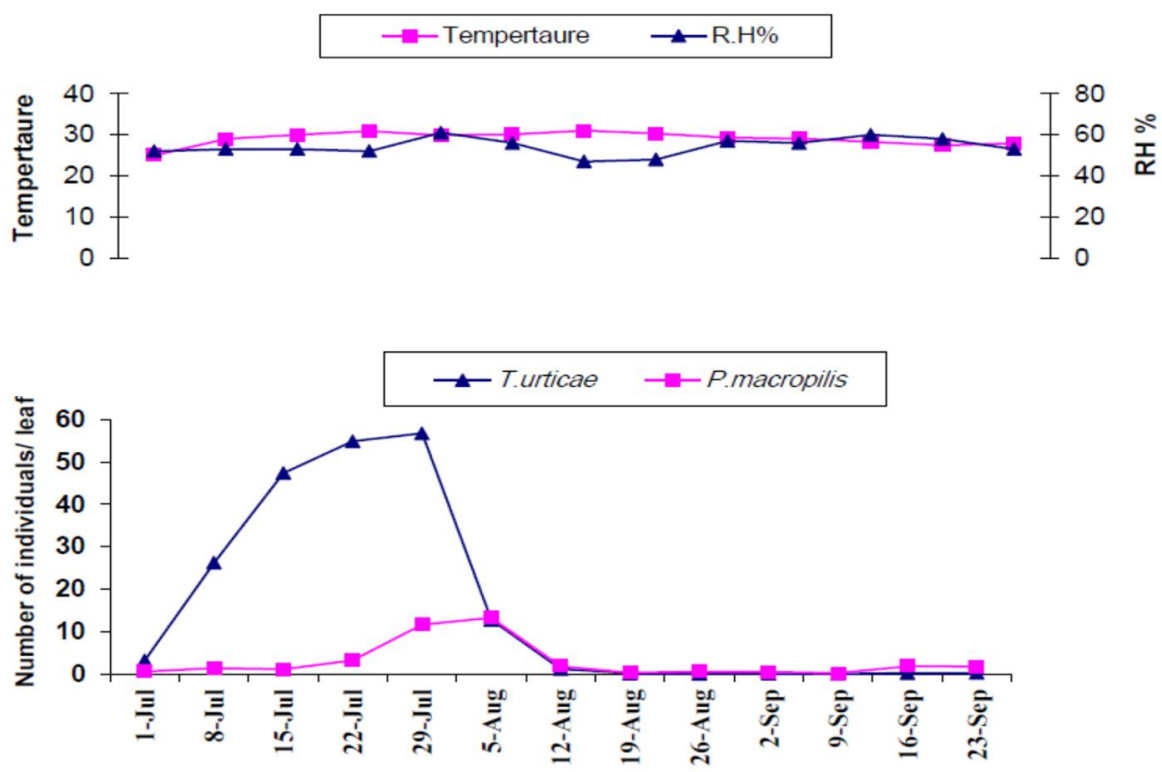

Inspection date

Fig 2. Population fluctuations of mites on soybean plants during season 2012.
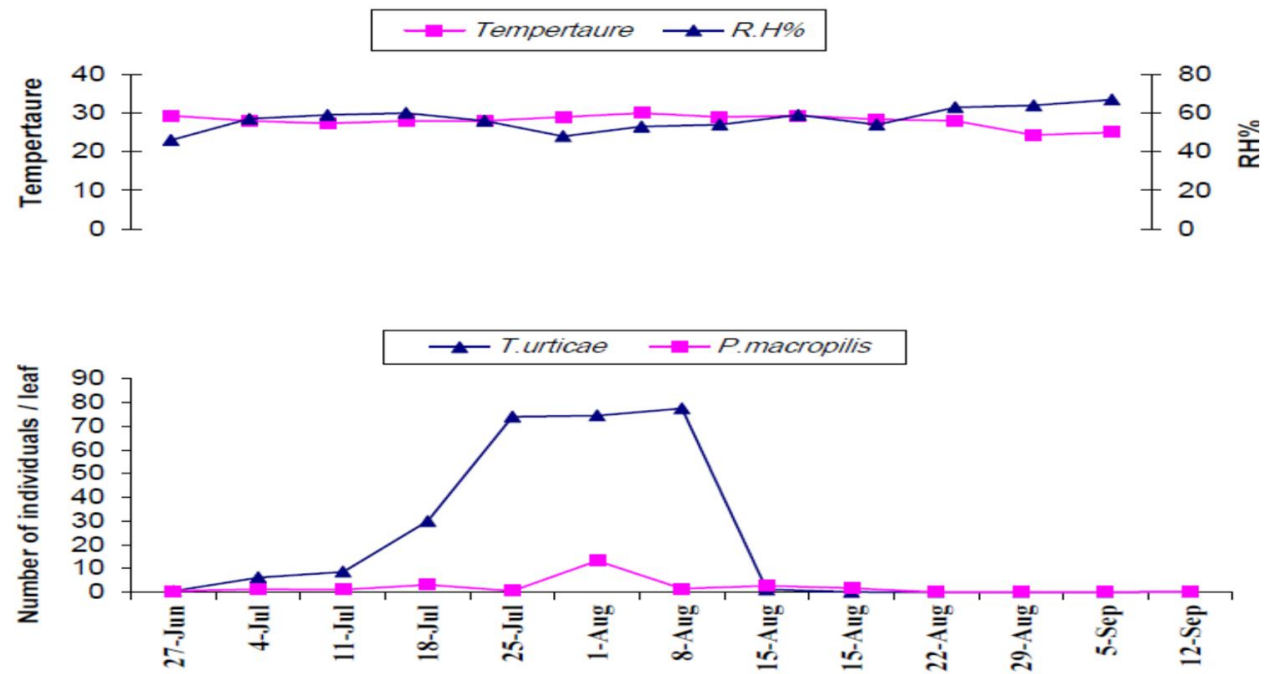

Inspection date

Fig 3. Population fluctuation of mites on soybean plants during season 2013. 
568 POPULATION FLUCTUATIONS OF CERTAIN MITES ASSOCIATED WITH SOYBEAN AND COTTON PLANTS IN RELATION TO CLIMATIC FACTORS AND LEAF PHYTOCHEMICAL CONTENTS

\subsubsection{Cotton:}

Data in Tables (4\&5) and Figs., (4\&5) revealed that the population of Tetranychus urticae Koch has two peaks in the first week of July and the first of August recording $17.23 \& 28.34$ individual / leaf, respectively in the first season (2012) while it was $17.75 \& 35.25$ individuals/leaf in the first week of July and last week of August, respectively in the second season (2013).

Data in Tables (4\&5) and Figs., (4\&5) showed that the population fluctuation of predacious mites $T$. californicus, $A$. exsertus and $A$. swirskii represented the highest peak in the first season 2012 and it was 5.0, 10.23 and 4.21 individuals / leaf, respectively. But the predacious mite E. scutalis recorded two peaks $7.35 \& 6.25$ individual / leaf in the second week of June and July respectively. While the second year (2013) T. californicus showed the highest peak (5.5 individuals/leaf), $A$. exsertus, A. swirskii and E. scutalis indicated two peaks $(6.25,11.25),(4.75,4.8)$ and $(7.7$, $6.75)$ individuals / leaf, respectively.

Data obtained in Tables (4\&5) showed that the total population of the phytophagous mite $T$. urticae was higher in the first season (394.92 individuals) compared with the second one (367.65 individuals/40leaves). On the other hand the predacious mites were high in the second year than that in the first one.

Obtained data in figures (4\&5) showed that there is a clear relation between the predacious mite species and the phytophagous mite species.

Table 4. Population fluctuations of mite species associated with cotton during season 2012.

\begin{tabular}{|c|c|c|c|c|c|c|c|}
\hline Inspection date & T. urticae & A. swirskii & E. scutalis & T. californicus & A. exsertus & $\begin{array}{c}\text { Mean } \\
\text { temperature }\end{array}$ & R.H\% \\
\hline April, $12^{\text {th }}$ & 3.92 & & 0 & 0 & 0 & 25.14 & 35.43 \\
\hline April,19th & 7.11 & & 0 & 0 & 0 & 25.86 & 40.86 \\
\hline April,24th & 9.5 & 0 & 2.5 & 0 & 0 & 24.71 & 48.86 \\
\hline May, $3^{\text {rd }}$ & 8.06 & 0 & 2.5 & 0 & 1.9 & 27.43 & 48.86 \\
\hline May, $10^{\text {th }}$ & 7.35 & 2.31 & 3.7 & 0 & 2.3 & 29.29 & 48 \\
\hline May, $17^{\text {th }}$ & 13.86 & 1.5 & 2.3 & 1.5 & 0 & 30.57 & 45.29 \\
\hline May, $24^{\text {th }}$ & 13.88 & 0.5 & 1.44 & 0 & 0 & 29.86 & 49.14 \\
\hline May,31th & 14.05 & 1.21 & 3.5 & 0 & 1.69 & 30.86 & 49.43 \\
\hline June, $7^{\text {th }}$ & 17.23 & 2.5 & 4.62 & 1 & 3.95 & 27.71 & 44.86 \\
\hline June, $14^{\text {th }}$ & 16.25 & 3.6 & 7.35 & 2.0 & 5.46 & 28 & 47.71 \\
\hline June,21th & 15.42 & 4.5 & 5.63 & 0.5 & 4.3 & 29.86 & 55 \\
\hline June, $28^{\text {th }}$ & 19.33 & 3.16 & 2.45 & 1 & 3.16 & 29.71 & 54.71 \\
\hline July, $5^{\text {th }}$ & 17.45 & 2.53 & 3.43 & 1 & 2.45 & 29 & 54.71 \\
\hline July, $12^{\text {th }}$ & 23.12 & 1.44 & 6.25 & 0 & 6.5 & 28.86 & 54 \\
\hline July, $19^{\text {th }}$ & 22.91 & 2.5 & 4.02 & 0 & 7.19 & 31.43 & 48.86 \\
\hline July, $26^{\text {th }}$ & 24.13 & 4.21 & 5.13 & 2.3 & 10.23 & 30 & 58.71 \\
\hline August,2rd & 28.34 & 3.12 & 2.5 & 4.2 & 7.15 & 30.29 & 57.57 \\
\hline August, $9^{\text {th }}$ & 27.18 & 0.5 & 3.4 & 5.0 & 4.13 & 30 & 53.57 \\
\hline August, $16^{\text {th }}$ & 21.73 & 1.2 & 2.75 & 4.0 & 3.92 & 31 & 44.57 \\
\hline August,23th & 22.51 & 0.9 & 1 & 1.5 & 2 & 29.71 & 54.57 \\
\hline August, $30^{\text {th }}$ & 17.22 & 1.5 & 3.11 & 0.7 & 1.32 & 33.43 & 63.86 \\
\hline September, $6^{\text {th }}$ & 18.13 & 1.31 & 0.9 & 1.2 & 3.5 & 28.57 & 59.29 \\
\hline September, $13^{\text {th }}$ & 15.66 & 0 & 1.11 & 1.5 & 1 & 27.71 & 58.57 \\
\hline September, $20^{\text {th }}$ & 10.58 & 0 & 1.35 & 0.5 & 0.5 & 27.71 & 52.43 \\
\hline Total & 394.92 & 38.49 & 70.94 & 27.9 & 72.65 & & \\
\hline
\end{tabular}


Table 5. Population fluctuations of mites associated with cotton plants during season 2013.

\begin{tabular}{|c|c|c|c|c|c|c|c|}
\hline Inspection date & T. urticae & A. swirskii & E. scutalis & T. californicus & A. exsertus & $\begin{array}{c}\text { Mean } \\
\text { temperature }\end{array}$ & R.H\% \\
\hline April, $12^{\text {th }}$ & 2.25 & 0 & 0 & 0 & 0 & 18.4 & 71 \\
\hline April, $19^{\text {th }}$ & 4.75 & 0 & 0 & 0 & 0 & 18.1 & 75 \\
\hline April, $24^{\text {th }}$ & 7.5 & 0 & 3.25 & 0 & 0 & 18.1 & 71 \\
\hline May, ${ }^{\text {rd }}$ & 7.25 & 0 & 2.8 & 0 & 2.1 & 24.25 & 60 \\
\hline May, $10^{\text {th }}$ & 7.75 & 2.5 & 4.4 & 1.5 & 2.5 & 25.3 & 69 \\
\hline May, $17^{\text {th }}$ & 10.5 & 1.75 & 2.8 & 2.25 & 0 & 23 & 66 \\
\hline May, $24^{\text {th }}$ & 12.00 & 1.00 & 1.95 & 0 & 1.65 & 27.1 & 60 \\
\hline May,31th & 12.7 & 1.35 & 4.25 & 1.25 & 1.9 & 25.3 & 53 \\
\hline June, $7^{\text {th }}$ & 14.7 & 3.35 & 5.25 & 0 & 4.25 & 27.15 & 58 \\
\hline June, $14^{\text {th }}$ & 15.5 & 3.6 & 7.7 & 2.0 & 6.25 & 26.35 & 63 \\
\hline June,21th & 15.75 & 4.75 & 6.15 & 0.75 & 4.4 & 24.05 & 71 \\
\hline June, $28^{\text {th }}$ & 17.75 & 3.5 & 2.8 & 1.6 & 3.55 & 24.75 & 72 \\
\hline July, th $^{\text {th }}$ & 16.5 & 3.05 & 4.35 & 1.65 & 2.8 & 25.35 & 72 \\
\hline July, $12^{\text {th }}$ & 25.5 & 1.6 & 6.75 & 0 & 7.25 & 24.6 & 72.5 \\
\hline July, $19^{\text {th }}$ & 30.25 & 3.25 & 4.75 & 2.0 & 7.19 & 25.6 & 68 \\
\hline July, $26^{\text {th }}$ & 30.75 & 4.8 & 5.75 & 2.55 & 11.25 & 25.86 & 68 \\
\hline August,2rd & 35.25 & 3.8 & 3.25 & 4.7 & 7.7 & 26.15 & 70 \\
\hline August, $9^{\text {th }}$ & 34.75 & 0.75 & 4.3 & 5.5 & 4.75 & 24.8 & 67.5 \\
\hline August, $16^{\text {th }}$ & 25.25 & 1.45 & 3.4 & 4.2 & 4.4 & 21.5 & 76.5 \\
\hline August,23th & 12.5 & 1.15 & 1.4 & 1.9 & 2.7 & 25.45 & 67 \\
\hline August, $30^{\text {th }}$ & 11.25 & 2.25 & 3.8 & 1.0 & 1.9 & 22.15 & 68 \\
\hline September, $6^{\text {th }}$ & 10 & 3.75 & 1.4 & 1.5 & 3.9 & 20.3 & 65 \\
\hline September, $13^{\text {th }}$ & 4.75 & 4.75 & 1.45 & 2.25 & 1.75 & 21.05 & 73.5 \\
\hline September, $20^{\text {th }}$ & 2.5 & 2.5 & 1.65 & 1.05 & 1.25 & 21.65 & 70.5 \\
\hline Total & 367.65 & 54.9 & 83.6 & 37.65 & 63.44 & & \\
\hline
\end{tabular}



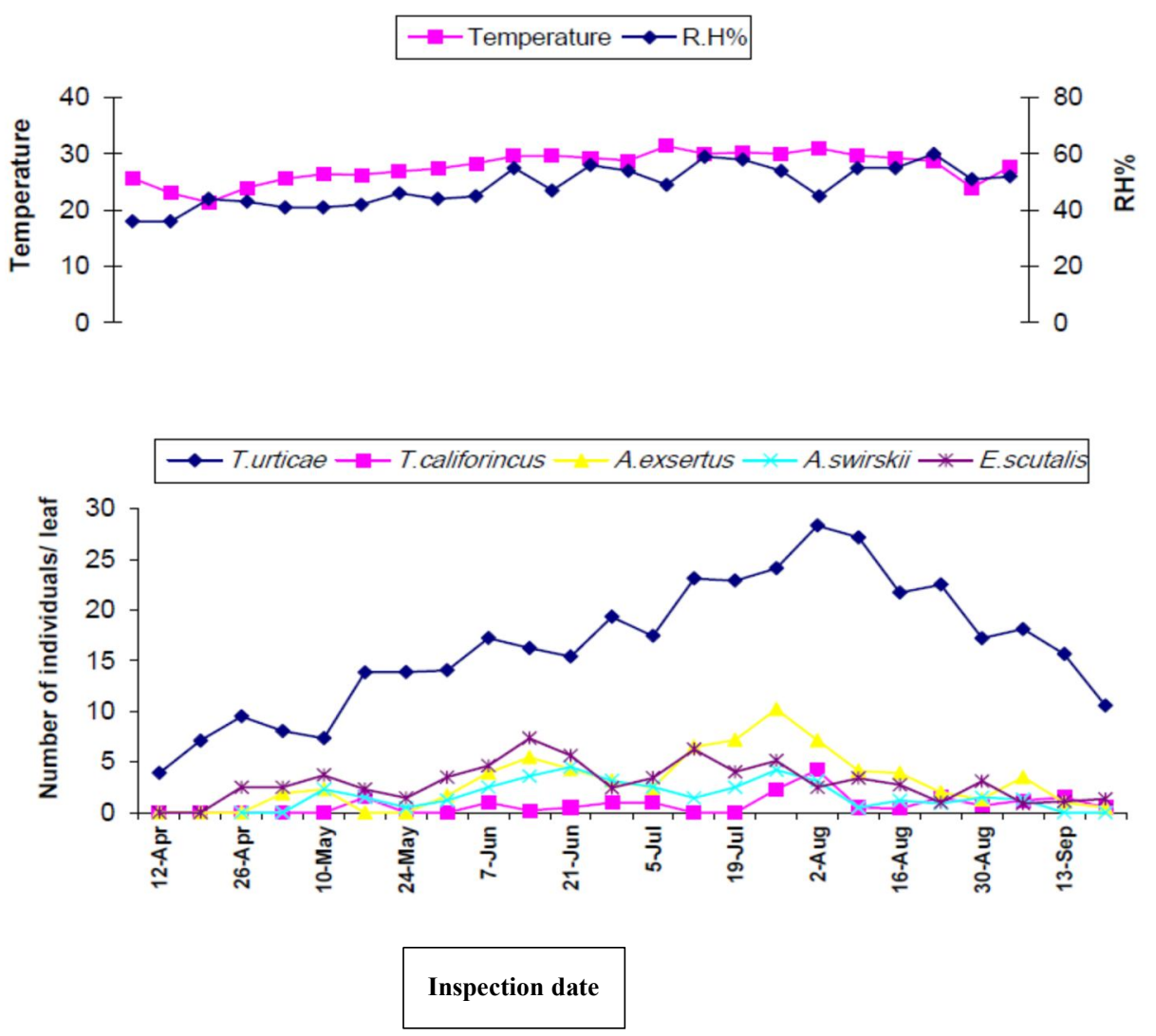

Fig 4. Population fluctuations of some mite species associated with cotton during season 2012.
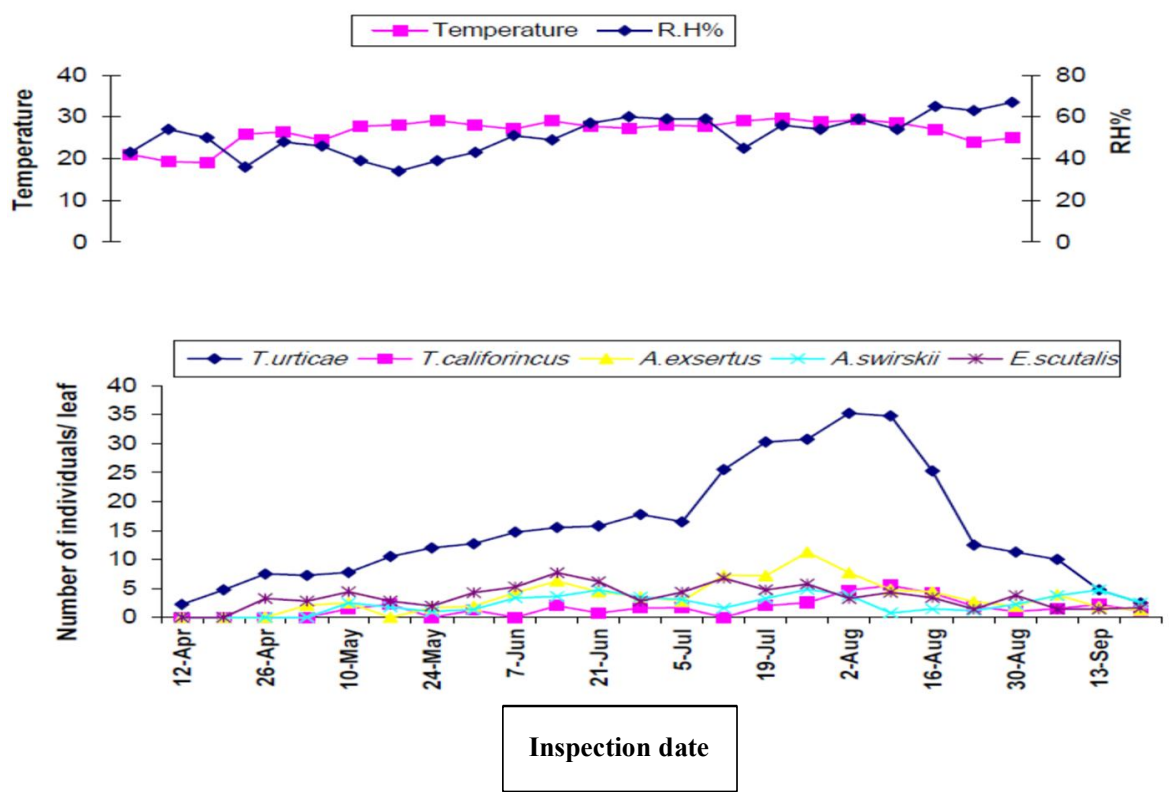

Fig 5. Population fluctuations of mites associated with cotton during season 2013 


\subsection{Statistical Analysis:}

\subsubsection{Correlation between the population of two mite species, some climatic factor and leaf chemical contents of soybean during two successive seasons 2012-13 (Tab., 6):}

The results of correlation coefficient analysis revealed positive relation between T.urticae and $P$. macropilis population and each of weekly temperature $(r=0.418$ \&0.302) and weekly mean R.H.\% $(r=0.142 \& 0.372)$ during 2012 season. During 2013 season the same results were found for temperature $(r=0.151 \& 0.201)$ for two mite species, respectively; and relative humidity for P.macropilis $(r=0.195)$ but differed with negative correlation for R.H\% ( $r=-0.323)$ fot T.urticae.

In regard to the relation between mite population and chemical content of soybean, the results showed no significant correlation between all measured chemical except reducing sugar with P. macropilis $\left(r=-0.619^{*}\right)$ during 2013 and protein + phosphorus with both mite species $(r=0.6166 *, 0.5614 *$ and $0.5494 *$, 0.6960*) during 2012 and 2013 seasons, respectively.

Table 6. Correlation coefficient values ( $r$ ) between two mite species and each of weekly mean temperature, relative humidity and leaf chemical contents of soybean during seasons 2012-13.

\begin{tabular}{|c|c|c|c|c|c|c|c|c|}
\hline Mite species & Temp. & R.H. & Total & Reducing & Nonreducing & Total & Total & Protein + \\
\hline \multicolumn{9}{|c|}{ Season 2012} \\
\hline T. urticae & 0.418 & 0.142 & 0.426 & 0.138 & 0.057 & -0.413 & -0.002 & $0.6166^{*}$ \\
\hline P. macropilis & 0.302 & 0.372 & 0.054 & 0.070 & 0.056 & 0.169 & -0.244 & $0.5614 *$ \\
\hline \multicolumn{9}{|c|}{ Season 2013} \\
\hline T. urticae & 0.151 & -0.323 & 0.093 & -0.338 & 0.196 & -0.400 & 0.142 & $0.5494 *$ \\
\hline P. macropilis & 0.201 & 0.195 & -0.276 & $-0.619 *$ & -0.153 & -0.317 & -0.149 & $0.6960 *$ \\
\hline
\end{tabular}

Also, the results indicated not stable trend for the effect of chemical components of soybean leaves on mite species population where the correlation values were differed as positive and negative significant from season to another for the same component and mite species except that of $P$. macropilis which had negative insignificant correlation with all chemical components during 2013 season. This results are partially agree with those of Gamieh and El-Basuony (2001), (De Angelis et al., 1983 and Wermelinger et al.; 1991) who mentioned a positive correlation between reducing sugar and mite population. 


\subsubsection{Correlation between the mite species of cotton and both temperature and R.H. during 2012:}

The correlation coefficient as shown in Table (7); revealed that there is highly significant correlation between the $T$. urticae and two predators Typhlodromus californicus \& Agistemus exsertus ( $r=0.563 \& 0.732)$, resp., as affected by temperature and relative humidity $(r=0.792 \& 0.720)$, resp., but it was significant between the $T$. urticae with Amblyseius swirskii ( $r=0.447$ ); while there was no significance between Euseius scutalis. The correlation coefficient revealed that there is no significant correlation between Typhlodromus californicus with Amblyseius swirskii, Euseius scutalis and Temperature. As exption appeared showing a highly significant correlation between R.H. ( $r=0.554)$, but it was significant between the Agistemus exsertus $(r=0.441)$. The correlation coefficient revealed that there is highly significant correlation between the Agistemus exsertus with Amblyseius swirskii and $A$. exsertus with Euseius scutalis $(r=0.679 \& 0.661)$., respectively, as affected by temperature and relative humidity $(r=0.669 \& 0.558)$. , respectively, but it was significant between the predator with the Typhlodromus californicus $(r=0.411)$. The correlation coefficient revealed that there is no significant correlation between Amblyseius swirskii and Typhlodromus californicus as affected by relative humidity. As exption appeared showing a highly significance between the predator with Agistemus exsertus and Euseius scutalis ( $r=0.679 \& 0.651)$, resp., as affected by temperature $(r=0.542)$.

The correlation coefficient revealed that there is no significant correlation between the Euseius scutalis and Typhlodromus californicus as affected by temperature and relative humidity. As exption appeared showing a highly significant correlation between $E$. scutalis with $A$. exsertus and $A$. swirskii $(r=0.661 \& 0.651)$, respectively.

Table 7. Correlation coefficient values $(r)$ between temperature, relative humidity and population fluctuations of mite associated with cotton during season 2012.

\begin{tabular}{|c|c|c|c|c|c|c|}
\hline \multirow{2}{*}{ Species } & \multicolumn{7}{|c|}{ Mite species } \\
\cline { 2 - 7 } & T. californicus & A. exsertus & A. swirskii & E. scutalis & Temp. & R.H. \\
\hline T. urticae & $0.563^{* * *}$ & $0.732^{* * *}$ & $0.447^{*}$ & 0.371 & $0.792^{* * *}$ & $0.720^{* * *}$ \\
\hline T.californicus & & $0.411^{*}$ & 0.379 & -0.065 & 0.352 & $0.554 * *$ \\
\hline A. exsertus & $0.411^{*}$ & & $0.679 * * *$ & $0.661^{* * *}$ & $0.669 * * *$ & $0.558^{* *}$ \\
\hline A. swirskii & 0.379 & $0.679 * * *$ & - & $0.651^{* *}$ & $0.542^{* *}$ & 0.256 \\
\hline E. scutalis & -0.065 & $0.661^{* * *}$ & $0.651^{* *}$ & & 03891 & 0.257 \\
\hline
\end{tabular}

$*=$ Significant

**= High significant

*** Highly significant 


\subsubsection{Correlation between the mite species of cotton and both temperature and R.H. during 2013:}

The correlation coefficient as shown in Table (8); revealed that there is highly significance between the pest mite $T$. urticae and with Typhlodromus californicus, Agistemus exsertus and Euseius scutalis ( $r=0.683,0.827$ and 0.538), resp. as affected by temperature $(r=0.621)$; while there was no significance between the predator with Amblyseius swirskii as affected by R.H.

The correlation coefficient revealed that there is no significant correlation between the predator Typhlodromus californicus with Amblyseius swirskii and Euseius scutalis as affected by relative humidity. As exption appeared showing significant correlation between the predator and Agistemus exsertus $(r=0.435)$ as affected by temperature $(r=0.478)$.

Table 8. Correlation coefficient values ( $r$ ) between temperature, relative humidity and population fluctuation of mite species associated with cotton during 2013.

\begin{tabular}{|c|c|c|c|c|c|c|}
\hline \multirow{2}{*}{ Species } & \multicolumn{6}{|c|}{ Mite species } \\
\cline { 2 - 7 } & californicus & A. exsertus & A. swirskii & E. scutalis & Temp. & R.H. \\
\hline T. urticae & $0.683^{* * *}$ & $0.827^{* * *}$ & 0.297 & $0.538^{* *}$ & $0.621^{* *}$ & 0.114 \\
\hline T. & & & & & & \\
californicus & ------ & $0.435^{*}$ & 0.269 & 0.138 & $0.478^{*}$ & 0.234 \\
\hline A. exsertus & $0.435^{*}$ & ----- & $0.578 * *$ & $0.657^{* * *}$ & $0.589 * *$ & 0.204 \\
\hline A. swirskii & 0.269 & $0.578 * *$ & ---- & $0.421^{*}$ & $0.433^{*}$ & 0.319 \\
\hline E. scutalis & 0.138 & $0.657^{* * *}$ & $0.421^{*}$ & ----- & $0.499 *$ & -0.118 \\
\hline
\end{tabular}

$*=$ Significant

$* *=$ High significant

*** Highly significant

The correlation coefficient revealed that there is no significant correlation between Amblyseius swirskii and Typhlodromus californicus as affected by R.H. As exption appeared showing significant correlation between $A$. swirskii with Euseius scutalis $(r=0.421)$ as affected by temperature $(r=0.433)$; also, they recorded the correlation coefficient sowing a highly significance between the predator and Agistemus exsertus ( $r=0.578)$.

The correlation coefficient revealed that there is highly significant correlation between the predator Euseius scutalis and Agistemus exsertus ( $r=0.657)$; while there was no significance difference between Typhlodromus californicus as affected by 
R.H., but it was significant between the predator with Amblyseius swirskii $(r=0.421)$ as affected by temperature $(r=0.499)$.

\subsubsection{Correlation between the mite species and leaf phytochemical contents of cotton leaves during 2013 (Table 9):}

The correlation coefficient revealed that there was highly significant between T. urticae with protein, carbohydrate, total sugar and reducing sugar $(r=0.812,0$, $74,0.675 \& 0.587)$, respectively; while there was no significance between the mite and nonreducing sugar.

The correlation coefficient revealed that there is no significant correlation between the predator Tyhplodromus californicus with protein, carbohydrate, reducing sugar and nonreducing sugar. As exption appeared showing significant correlation between $T$. californicus with total sugar $(r=0.431)$.

The correlation coefficient revealed that there is significant correlation between the Agistemus exsertus and carbohydrate, total sugar and reducing sugar ( $r$ $=0.502,0.465 \& 0.407)$, respectively. They also recorded the correlation coefficient showing a highly significant correlation between the predator and protein $(r=0.551)$; while there was no significance between the predator and nonreducing sugar.

The correlation coefficient revealed that there is no significant correlation between the two predators ( $A$. swirskii \& E. scutalis) with leaf phytochemical contents.

Table 9. Correlation coefficient values $(r)$ between leaf phytochemical and population fluctuations of mites associated with cotton during 2013.

\begin{tabular}{|c|c|c|c|c|c|}
\hline \multirow{2}{*}{ Mite Species } & \multicolumn{5}{|c|}{ Some Phytochemical Contents } \\
\cline { 2 - 6 } & Protein & Carbohydrate & Total sugar & $\begin{array}{c}\text { Reducing } \\
\text { sugar }\end{array}$ & $\begin{array}{c}\text { Nonreducing } \\
\text { sugar }\end{array}$ \\
\hline T. urticae & $0.812^{* * *}$ & $0.740^{* * *}$ & $0.675^{* * *}$ & $0.587^{* *}$ & 0.201 \\
\hline T. californicus & 0.403 & 0.399 & $0.431 *$ & 0.184 & 0.291 \\
\hline A. exsertus & $0.551^{* *}$ & $0.502^{*}$ & $0.465^{*}$ & $0.407^{*}$ & 0.136 \\
\hline A. swirskii & 0.276 & 0.299 & 0.187 & 0.190 & 0.263 \\
\hline E. scutalis & 0.313 & 0.304 & 0.162 & 0.279 & -0.070 \\
\hline
\end{tabular}

\footnotetext{
$*=$ Significant

$* *=$ High significant

*** Highly significant
} 
These results coincided with those obtained by Omar et al., (2013) they studied interrelation between Oligonychus pratensis and Amblyseius zaheri with both temperature and relative humidity; they declared that no significance relationship between $O$. paratensis and $A$. zaheri as affected by temperature and R.H. at the both localities during both seasons. As exption appeared showing significant correlation between A. zaheri with R.H. at the two Governorates at both seasons. The correlation coefficient revealed that there is highly significance between the pest mite and its predator during the second season at El-Sharkia Governorate $(r=0.929)$; while there was no significance during the first season $(r=0.044)$. In El-Dakahlia, the correlation coefficient revealed that there is no significance $(r=0.060 \& 0.311)$ at both seasons, respectively.

\section{REFERENCES}

1. A.O.A.C. 2000. Official methods of analysis of association of official agriculture chemists, published by the A.O.A.C., Washington D.C.

2. De Angelis, J.D.; R. E. Berry and G.W. Krantz. 1983. Evidence for spider mite (Acari: Tetranychidae) injury- induced leaf water deficits and osmatic adjustment in peppermint. Environmental Entomo.12, 336-339.

3. El-Khouly, A.S.; E.M. E. Khalafalla.; M.M. Metwally; H.A. Helal and A.B. ElMezaien. 1998. Seasonal abundance and population dynamics of certain sucking insects on soybean at Kafr El-Sheikh Governorate Egypt. Egypt. J. Agric. Res., 76 (1): 141-151.

4. Hildebrand, D.F.; J. G. Rodriguezi; G.C. Brown and C.S. Volden. 1986. Two spotted spider mite (Acari: Tetranychidae) infestations on soybean: Effect on composition and growth of susceptible and resistant cultivars. J. Econ. Entomol., 79 (4): 914-921.

5. Gamieh, G.N. and Asmaa A. El-Basuony. 2001. Population densities of piercing sucking pests in soybean fields as influenced by varieties, predators and leaf physical and chemical properties. J. Agric. Sci. Mansoura Univ., 26 (2): 10891099.

6. Jackson, M. L. (1970): Soil chemical analysis. Prentica Hall, Englewood Cliffs, N. J.11-77pp.

7. John, W. N.JR; S. Marla and M. Katherine. 1986. Toxicity of clorfentezine against the two spotted and carmine spider mite (Acari: Tetranychidae). J. Econ. Entomol. 79 (2): 479-483. 
8. Kumar, R. 1984. Insect pest control with special reference to African agriculture. Edward Arnold, London. 298pp.

9. McAuslane, H.J.; F.A. Johnson; D.L. Colvin and B. Sojack. 1995. Influncence of foliar pubescence on abundance and parasitism of Bemisia argentifolii (Homoptera: Aleyrodidae) on soybean. Environ. Entomol., 24 (5): 1135-1143.

10. McAuslane, H.J. 1996. Influence of leaf pubescence on ovipositional preference of Bemisia argentifolii (Homoptera: Aleyrodidae) on soybean and peanut. Environ. Entomol., 24 (4): 834-841.

11. Metcalf, R.L. and L. H. William. 1975. Introduction to insect pest management. New York. 587pp.

12. Nabil, A. Omar; O.M.O.Mohamed and Mariam, A. El-Sanady. 2013. Population fluctuations of Oligonychus pratensis (Banks) and its predatory Amblyseius zaheri Yousef\& El-Brollosy in Egypt (Tetranychidae, Phytoseiidae) Research J. Agric \& Biol. Sci., 9 (2): 89-95.

13. Taha.H. A.; Amira A. Shoeib; Ahlam A. Younes and M.A. Ahmed. 2001. Susceptibility of ten soybean varieties to some sucking pests with respect to certain climatic factors infectiveness. J. Agric. Sci. Mansoura Univ., 26 (8): 50595066.

14. Wermelinger, B.; J. J.; Oertli and J. Baumgärtner. 1991. Environmental factors influencing the life-tables of Tetranychus urticae (Acari: Tetranychidae). III. Host-plant nutrition. Experimental and Applied Acarology 12: 259-274.

15. Wilson, L. T.; P.J. Trichilo, and D. Gonzalez. 1993. Spider mite (Acari: Tetranychidae) infestation rate and initiation effect on cotton yield. J. Econ. Entomol., 84 (92): $593-600$.

16. Zaher, M.A.; M.A. Hanna; I.I. Mohamed and Z. R. Sawires. 1980. Relative susceptibility of ten soybean varieties to mite infestation and probable causes resistance. Proc. $1^{\text {st }}$ Conf., Plant Prot. Res. Ins., 3: 41-51. 
تذبذب التعداد لبعض الأكاروسات المرتبطة بمحصولي فول الصويا والقطن

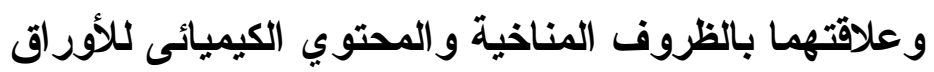

$$
\begin{aligned}
& \text { فاطمة شحاتة قلموش' ، عزت فرج الخياط'، جاد حماده حسن راضي"، }
\end{aligned}
$$

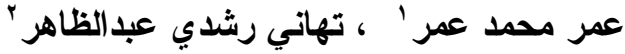

$$
\begin{aligned}
& 1 \text { - معهل بحوث وقاية النباتات - مركز البحوث الزراعية - الجيزة - مصر. } \\
& \text { r- قسم وقاية النبات - كلية الزراعة - جامعة بنها - مصر. }
\end{aligned}
$$

تمت دراسة تنبذب التعداد لبعض الأكاروسات المرتبطة بمحصولي القطن وفول الصويا خلال

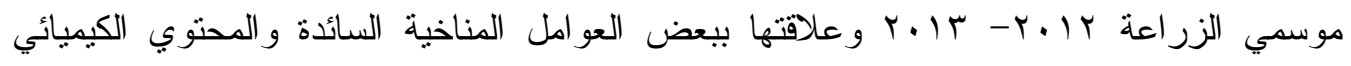
لكلأوراق.

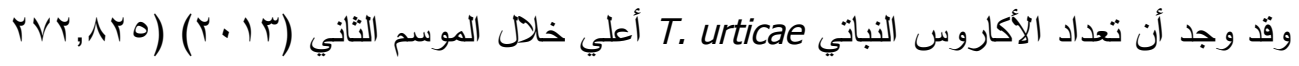

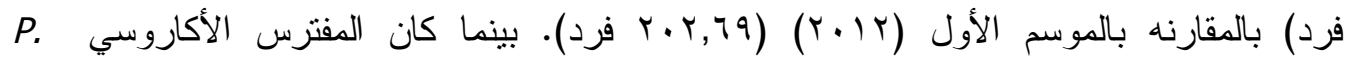
macropilise

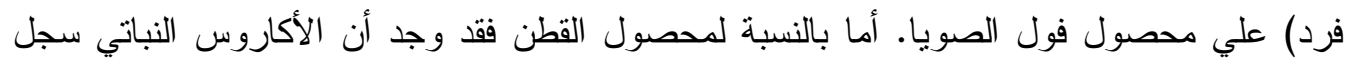

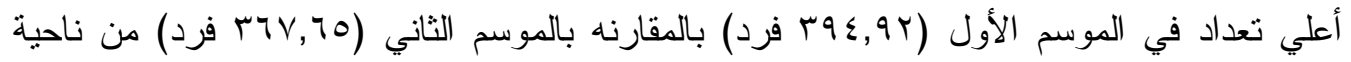

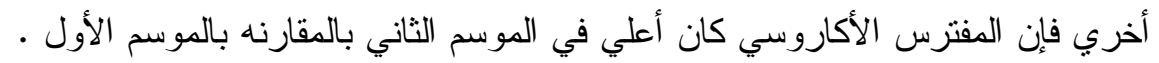

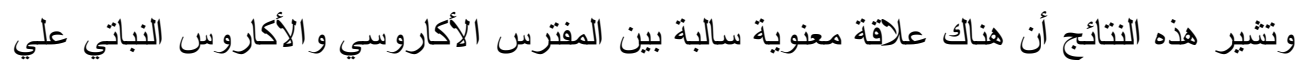

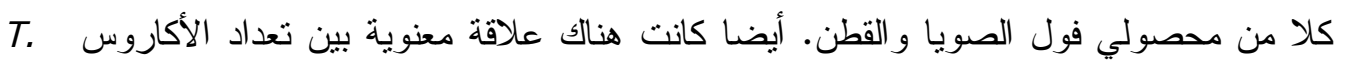
و عنصري البروتين و الفسفور كأحد مكونات ورقة نبات فول الصويا. بينما نوجد علاقة الإنة

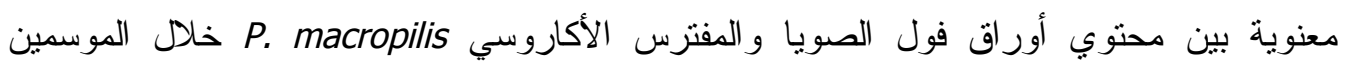
$. r \cdot \mid r-r \cdot 1 r$

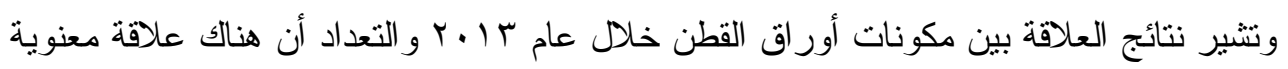

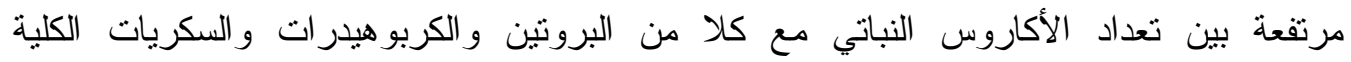

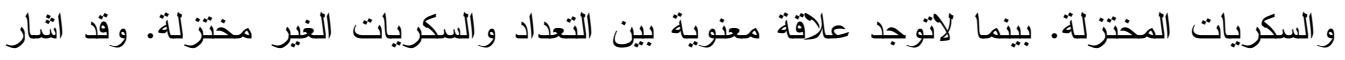

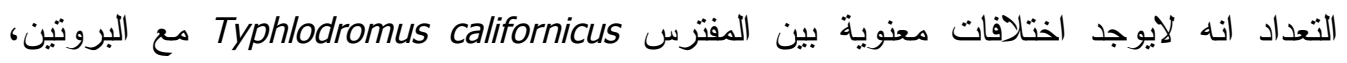

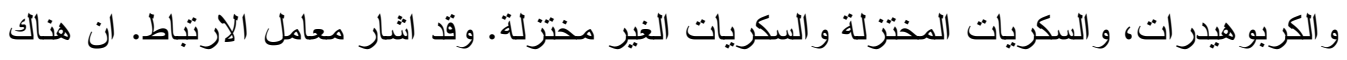
اختلافات معنوية بين تعداد Agistemus exsertus وكلا من الكربوهيدرات و السكريات الكلية و السكريات المختزلة، وقد سجل ايضا علاقة اختلافات معنوية مرتفعة بين المفترس و البروتين ; بينما لاتوجد اختلافات معنوية بين كلا من A. swirskii و و المحتوي الكيميائي للاور اق. 